\title{
Resistance Level of Crocidolomia pavonana Against Profenofos Synthetic Insecticide and its Susceptibility To Azadirachta Indica Seed Extract
}

\author{
Danar Dono $^{1 *}$, Yogas Dwi Pratiwi ${ }^{1}$, Safri Ishmayana ${ }^{2}$, Djoko Prijono $^{3}$ \\ ${ }^{1}$ Department of Plant Pests and Diseases, Agriculture Faculty, Universitas Padjadjaran, Jatinangor, West Java, \\ Indonesia, 45363. \\ ${ }^{2}$ Departement of Chemistry, Faculty of Mathematic and Natural Sciences, Universitas Padjadjaran, Jatinangor, West \\ Java Indonesia, 45363. \\ ${ }^{3}$ Departement of Plant Protection, Agriculture Faculty, Institut Pertanian Bogor, Dramaga, Jawa Barat, Indonesia, \\ 16680.
}

*Corresponding Author: danar.dono@unpad.ac.id

\begin{abstract}
This research was conducted to know resistance level of Crocidolomia pavonana to a profenofos synthetic insecticide and to know susceptibility of $C$. pavonana to Azadirachta indica seed extract. The experiment using two bioassay methods, dry film method and feeding method. Field population of $C$. pavonana obtained from 3 villages in Lembang district i.e.Cibogo, Cikole and Kayu Ambon village. The standard insect has been maintenance more than 20 generations in the laboratory as a comparison. The result of the experiment indicated that population of C. pavonana form Cikole, Cibogo and Kayu Ambon village were resistant to profenofos insecticide with resistance ratio (RR) was low $(1<\mathrm{RR} \leq 5)$. Resistance Ratio of $C$. pavonana from the third village were 4.69 and $4.83 ; 1.02$ and 1.1 and 1.16 and 1.9 respectively (dry film and feeding method). The value of the resistance ratio was greater through the feeding assay compared to the contact assay. This indicated that the mechanism of $C$. pavonana resistance was likely to occur mainly in the digestive tract of insects. Enzime activity of the different sample population of C. pavonana indicated variation in their activity. This was indicated that every sample from different field could develop different mechanism of resistance. The toxicity study of $A$. indica seed extract to C. pavonana indicate that the field population of $C$. pavonana from the third village was susceptible to seed extract of $A$. indica with value RR of less than one point. Therefore seed extract of $A$. indica could be used as alternative control against C. pavonana which resistant to profenofos synthetic insecticide.
\end{abstract}

Keywords: Resistance mechanism, Resistance ratio, Synthetic insecticide, Botanical insecticide

\section{ABSTRAK \\ Tingkat Resistensi Crocidolomia pavonana Terhadap Insektisida Sintetik Profenofos dan Kepekaannya Terhadap Ekstrak Biji Azadirachta indica}

Penelitian bertujuan untuk mengetahui tingkat resistensi larva Crocidolomia pavonana terhadap insektisida sintetik profenofos dan menguji kepekaan $C$. pavonana yang resisten terhadap ekstrak biji Azadirachta indica. Pengujian menggunakan metode kontak dan metode perlakuan pakan. Larva populasi lapang diperoleh dari sentra produksi sayuran di Kabupaten Lembang yaitu Desa Cibogo, Cikole dan Kayu Ambon. Sebagai serangga pembanding digunakan larva $C$. pavonana standar yang telah dipelihara dilaboratorium lebih dari 20 generasi. Hasil percobaan menunjukkan bahwa populasi C. pavonana asal desa Cikole, Cibogo dan Kayu Ambon resisten terhadap insektisida profenofos dengan tingkat nisbah resistensi (NR) resistensi rendah $(1<\mathrm{NR} \leq 5)$. Nisbah Resistensi $C$. pavonana dari ketiga desa tersebut berturut-turut 4,69 dan 4,83; 1,02 dan 1,1 serta 1,16 dan 1,9 baik untuk pengujian efek kontak maupun perlakuan pakan. Nilai nisbah resistensi lebih besar melalui metode uji perlakuan pakan dibanding dengan metode kontak. Hal ini mengindikasikan bahwa mekanisme resistensi $C$. pavonana kemungkinan terutama terjadi pada saluran pencernaan serangga. Hasil pengujian aktivitas enzim menunjukkan bahwa setiap sampel dari daerah yang berbeda memiliki aktivitas yang berbeda. Hail ini mengidikasikan bahwa setiap populasi padat mengembangkan system ezimatik detoksifikasi yang berbeda. Hasil pengujian toksisitas ekstrak biji $A$. indica terhadap ketiga populasi $C$. pavonana lapang melalui metode perlakuan pakan menunjukkan bahwa larva tersebut peka terhadap ekstrak biji $A$. indica dengan nilai NR kurang dari satu. Dengan demikian ekstrak biji $A$. indica berpeluang digunakan untuk pengendalian $C$. pavonana yang resisten terhadap insektisida sintetik profenofos.

Kata kunci: Mekanisme resistensi, Nisbah resistensi, insektisida sintetik, Insektisida botani.

\section{PENDAHULUAN}

Resistensi serangga hama merupakan salah satu dampak negatif penggunaan insektisida yang tidak bijaksana selain dampak terbunuhnya musuh alami, ledakan hama sekunder, resurjensi, serta pencemaran lingkungan dan masalah kesehatan (Aktar et al.,2009; Food Agricultural Organization [FAO], 2012). Insektisida yang diaplikasikan tanpa pengetahuan yang menyeluruh tentang sifat-sifat dasar insektisida sintetis, dapat mengakibatkan terjadinya peningkatan populasi hama yang resisten. Penggunaan insektisida yang hanya satu jenis dan secara terus menerus dengan peningkatan dosis dan frekuensi aplikasi, dapat menimbulkan dampak resisten terhadap serangga hama tanaman (Untung, 2006). Munculnya serangga resisten terhadap insektisida sintetik yang digunakan dapat mengakibatkan 
terjadinya kegagalan pengendalian secara kimiawi terhadap serangga hama di lapangan.

Santoso (1997) melaporkan bahwa $C$. pavonana dari daerah Bandung menunjukkan Nisbah Resistensi (NR) tertinggi yaitu 15,4; kemudian diikuti secara berturut-turut 7,4; 7,0; dan 4,1 masing-masing NR $C$. pavonana dari daerah Pacet, Simpang ampat, dan Sukabumi, sedangkan Uhan \& Sulastrini (1993) sebelumnya melaporkan bahwa $C$. pavonana belum menunjukkan gejala resisten terhadap beberapa insektisida yang diuji. Resitensi $C$. pavonana juga dilaporkan oleh Suharti (2000) di daerah Cikandang dan Cibogo (Kecamatan Lembang, Kabupaten Bandung) dengan NR berturut-turut 7,88dan 6,81. Dono et al (2014) melaporkan bahwa populasi $C$ pavonana di kabupaten Garut menunjukkan tingkat resistensi rendah dengan nisbah resistensi 1,04; 1,65; dan 1,20 (metode kontak) dan 1,23; 186; dan 1,42 (metode perlakuan pakan) berturut-turut untuk larva yang berasal dari desa Karyamekar, Sirnajaya dan Padasuka.

Hasil survei yang kami lakukan menunjukkan bahwa upaya pengendalian $C$. pavonana di daerah Lembang, Kabupaten Bandung, sampai saat ini masih mengandalkan pada penggunaan insektisida sintetik berbahan aktif profenofos. Hal ini sejalan dengan yang dikemukakan oleh Sastrosiswojo (1987) dan Soeriaatmadja \& Duskarno (1990) bahwa insektisida sintetis yang sering digunakan untuk pengendalian hama tersebut adalah profenofos selain insektisida berbahan aktif permetrin, sipermetrin, dekametrin, protiofos dan asefat.

Berkembangnya $C$. pavonana yang resisen terhadap insektisida sintetik profenofos perlu diatasi, salah satunya dengan mencari sumber insektisida baru yang lebih efektif dan aman terhadap lingkungan serta diperlukan adanya pemantauan secara terus menerus terhadap perkembangan status resistensi hama. Salah satu sumber insektisida yang dapat dikembangkan untuk pengendalian hama adalah insektisida asal tumbuhan. Salah satu tumbuhan yang berpotensi untuk mengendalikan $C$. pavonana adalah Azadirachta indica (Meliaceae). Ekstrak biji A. indica telah lama digunakan sebagai insektisida (Schmutterer, 1995). Ekstrak A. indica dilaporkan aktif terhadap setidaknya 400 spesies serangga yang tergolong ordo Lepidoptera, Orthoptera, Coleoptera,Diptera,Hemiptera, Hymenoptera, Homoptera, Blattodea, Thysanoptera, (Schmutterer \& Singh 1995). Ekstrak metanol biji A. indica memiliki kandungan azadirakhtin yang bersifat sebagai penghambat perkembangan serangga (Barnby \& Klocke,1990). Selain itu, A. indica juga mengandung salanin yang berfungsi sebagai antifeedant (penghambat makan) terhadap larva serangga, melantriol yang berfungsi sebagai penghalau (repellent) (Sharma et al. 1984; Isman et al. 1995). Kraiss \& Cullen (2008) melaporkan bahwa azadirakhtin dan minyak mimba efektif mengakibatkan kematian nimfa Aphis glycines berturut-turut sebesar 80 and $77 \%$.

Sebagai mana telah diuraikan terdahulu, kasus resistensi serangga hama $C$. pavonana terhadap insektisida sintetik profenofos dapat terus berkembang, sehingga pemantauan perkembangan resistensi serangga hama terhadap insektisida sintetik perlu dilakukan secara berkala agar deteksi resistensi dapat dilakukan secara dini dan strategi pengelolaan resistensi dapat dirancang jauh sebelum terjadinya resistensi (Soemawinata dkk., 1993). Dalam penelitian ini akan dipelajari tingkat resistensi $C$. pavonana terhadap insektisida berbahan aktif profenofos dan kepekaan serangga tersebut terhadap insektisida botani ekstrak biji $A$. indica.

\section{BAHAN DAN METODE}

Penelitian dilaksanakan pada Juli 2009 sampai April 2010 di Laboratorium Pestisida dan Toksikologi Lingkungan, Departemen Hama dan Penyakit Tumbuhan, Fakultas Pertanian, Universitas Padjadjaran, Jatingangor, Jawa Barat, Indonesia.

Pengujian resistensi dilakukan melalui beberapa tahap, yaitu penentuan tingkat kepekaan acuan, penentuan tingkat resistensi terhadap insektisida berbahan aktif profenofos dan penentuan tingkat kepekaan serangga yang terindikasi resisten terhadap ekstrak biji $A$. indica .

\section{Insektisida Uji}

Insektisida yang digunakan berbahan aktif profenofos (golongan organofosfat) dari formulasi komersial Curacron 500 EC. Pengencer yang digunakan adalah akuades yang telah diberi pengemulsi alkilaril poliglikol eter $400 \mathrm{mg} / \mathrm{l}$ $\left(\right.$ Agristic $^{\mathrm{R}}$ ) 0,1\%.

\section{Insektisida Botani Uji Ekstrak Biji Azadirachta indica}

Biji A. indica .diperoleh dari daerah Situ Bondo, Jawa Timur. Biji A. indica kering udara dihaluskan menggunakan blender, kemudian direndam dalam pelarut metanol dengan perbandingan biji : pelarut (1 : 8). Larutan ekstrak biji kemudian disaring menggunakan kertas saring Whatman No. 41. Larutan hasil penyaringan kemudaian diuapkan pelarutnya menggunakan rotary evaporator pada suhu $45^{\circ} \mathrm{C}$ dan tekanan rendah. Ekstrak pekat yang diperoleh disimpan dalam lemari es pada temperatur $4^{\circ} \mathrm{C}$ hingga saat digunakan untuk pengujian.

\section{Larva Uji}

Larva uji yang digunakan terdiri dari dua kelompok yaitu kelompok larva standar dan, kelompok larva lapangan. Larva standar diperoleh dari koloni di Laboratorium Fisiologi dan Toksikologi Serangga Departemen Proteksi Tanaman Fakultas Pertanian Institut Pertanian Bogor yang dipelihara dalam keadaan bebas pestisida dan telah melampaui 20 generasi, sedangkan larva lapangan diperoleh dari 3 desa yaitu Desa Cibogo, Cikole dan Kayu Ambon di Kecamatan Lembang, Kabupaten Bandung Barat, Jawa Barat. Larva yang berasal dari lapangan yang 
digunakan ialah instar 2 dari generasi F2 dan F3. Pemeliharaan serangga uji mengikuti prosedur yang dikemukakan oleh Prijono \& Hassan (1992).

\section{Penentuan Data Kepekaan Acuan}

Metode pengujian insektisida terhadap larva uji yang digunakan adalah metode kontak (metode residu pada permukaan tabung gelas) dan metode perlakuan pakan (metode residu pada daun pakan atau metode celup pakan).

\section{Metode Kontak}

Konsentrasi formulasi insektisida yang digunakan yaitu lima taraf yang diharapkan mengakibatkan kematian serangga uji antara $0<\mathrm{X}<$ $100 \%$ serta kontrol. Konsentrasi tersebut ditentukan berdasarkan uji pendahuluan. Konsentrasi larutan insektisida dibuat dengan mengencerkan formulasi insektisida pada volume tertentu dalam pengencer akuades dan pengemulasi alkilaril poliglikol eter 400 $\mathrm{mg} / \mathrm{l}\left(\right.$ Agristik $\left.^{\mathrm{R}}\right) \quad 0,1 \%$. Sediaan insektisida pada konsentrasi tertentu dimasukkan ke dalam tabung gelas (tinggi $6 \mathrm{~cm}$ dan diameter $2,2 \mathrm{~cm}$ ) sampai penuh. Setelah beberapa waktu penggenangan, larutan insektisidadituang dan tabung gelas pengujian dikeringudarakan. Setelah kering (pengencernya menguap), tabung siap digunakan sebagai wadah pengujian. Setiap taraf konsentrasi dan kontrol diulang 6 kali. Sebanyak 10 ekor larva instar 2 standar atau lapangan dimasukkan ke dalam setiap tabung gelas pengujian dengan menggunakan kuas halus. Waktu saat pemasukan serangganya dicatat. Setelah dua jam larva berada dalam tabung pengujian kontak dengan insektisida, larva dikeluarkan dan dimasukkan ke dalam cawan petri (diameter $9 \mathrm{~cm}$ ). Sebelumnya ke dalam wadah telah dimasukkan pakan daun brokoli segar secukupnya. Selanjutnya pengamatan kematian dilakukan 48 jam setelah perlakuan. Hubungan antara konsentrasi insektisida dengan tingkat kematian larva serangga uji dilakukan dengan menggunakan analisis probit dengan program POLO-PC Le Ora software (1987).

\section{Metode Perlakuan Pakan}

Konsentrasi formulasi insektisida yang digunakan yaitu lima taraf yang diharapkan mengakibatkan kematian serangga uji antara $0<\mathrm{X}<$ $100 \%$. Konsentrasi tersebut ditentukan berdasarkan uji pendahuluan. Cara pengenceran larutan insektisida dialkukan dengan cara yang sama seperti pada percobaan terdahulu. Daun brokoli dipotong-potong berbentuk bujur sangkar berukuran $4 \times 4 \mathrm{~cm}^{2}$ yang kemudian dicelupkan ke dalam setiap larutan insektisida sampai seluruh permukaan daun basah merata.Daun tersebut kemudian dikeringudarakan sebelum digunakan sebagai pakan larva. Daun brokoli berperlakuan dan kontrol dimasukkan ke dalam cawan petri (diameter $9 \mathrm{~cm}$ ) yang telah dialasi kertas tisu. Sebanyak 10 ekor larva instar 2 standar dan larva lapangan dimasukkan ke dalam masing-masing wadah. Tiap perlakuan diulang 6 kali. Daun berperlakuan diberikan selama 24 jam. Selanjutnya larva diberi pakan daun brokoli segar (tanpa perlakuan). Pengamatan dilakukan pada 48 jam setelah perlakuan terhadap jumlah larva yang mati.

Hubungan antara konsentrasi insektisida dengan tingkat kematian larva serangga uji pada kedua metode pengujian dianalisis dengan menggunakan analisis probit dengan program POLOPC Le Ora software (1987).

\section{Penentuan Tingkat Resistensi}

Pengujian toksisitas insektisida profenofos terhadap populasi lapangan dilakukan pada 6 taraf konsentrasi insektisida ditambah kontrol, dengan tahap pekerjaan seperti pada penentuan tingkat kepekaan acuan.

Sebagai tolok ukur resistensi, digunakan Nisbah Resistensi (NR) yang dihitung dengan rumus sebagai berikut:

$$
\mathrm{NR}=\frac{\mathrm{LC}_{50} \text { populasi lapangan }}{\mathrm{LC}_{50} \text { populasi standar }}
$$

Serangga $C$. pavonana yang berasal dari populasi lapang dikategorikan dalam 3 tingkat resistensi sebagai berikut: Resistensi rendah $(1<\mathrm{NR}$ $\leq 5)$, Resistensi sedang $(5<\mathrm{NR} \leq 10)$ Resistensi tinggi (NR > 10) (Rodríguez et al., 2007).

\section{Uji Kepekaan Serangga Resistensi terhadap Insektisida Botani}

Populasi C. pavonana yang resisten diuji kepekaannya terhadap insektisida botani ekstrak biji A. indica. Pengujian dilakukan dengan menggunakan metode perlakuan pakan. Ekstrak diuji pada lima taraf konsentrasi yang dapat mematikan larva pada kisaran $0<\mathrm{X}<100 \%$ yang ditentukan berdasarkan uji pendahuluan.

Larutan dengan konsentrasi yang diinginkan dibuat dengan melarutkan ekstrak dengan berat tertentu dalam campuran aseton-metanol (3:1). Daun brokoli berukuran $4 \mathrm{x} 4 \mathrm{~cm}$ dicelupkan ke dalam larutan ekstrak sampai terbasahi merata dengan konsentrasi yang telah ditentukan, kemudian dikeringudarakan. Setelah pelarut menguap, dua potong daun perlakuan diletakkan dalam cawan petri berdiameter 9 cm yang dialasi kertas tisu. Selanjutnya, ke dalam setiap cawan petri dimasukkan 10 ekor larva $C$. pavonana instar 2 awal. Larva kontrol diberi pakan daun yang hanya dicelupkan dalam pelarut sesuai dengan pelarut sediaan yang digunakan. Pemberian pakan daun perlakuan dilakukan selama 48 jam, selanjutnya larva diberi pakan daun tanpa perlakuan hingga mencapai instar 4.Percobaan disusun dalam rancangan acak lengkap dengan 4 ulangan. Penentuan nilai $\mathrm{LC}_{50}$ dilakukan dengan analisis probit menggunakan POLO-PC Le Ora software (1987).

Sebagai tolak ukur kepekaan serangga terhadap insektisida botani, digunakan Nisbah Resistensi (NR) yang dihitung dengan menggunakan rumus yang sama seperti pada uji penentuan tingkat resistensi. Jika NR $<1$ berarti serangga yang berasal dari populasi 
lapangan (resisten terhadap insektisida sintetis tertentu) peka terhadap insektisida botani.

\section{Analisis Aktivitas Enzim yang terkait resistensi Ekstraksi enzim}

Sebanyak $16 \mathrm{~g}$ larva $C$. paconana instar 3 ditambah dengan $160 \mathrm{~mL}$ buffer fosfat $0,1 \mathrm{M} \mathrm{pH} \mathrm{7,5}$ (1:10) dihomogenisasi dengan menggunakan Potter Elvehjem homogenizer pada suhu dingin. Homogenat yang diperoleh disentrifugasi dengan kecepatan 5000 rpm selama 30 menit pada suhu $4^{\circ} \mathrm{C}$. Supernatan hasil sentrifugasi kemudian ditambahkan dengan garam ammonium sulfat sampai kejenuhan $100 \%$, dan disentrifugasi kembali dengan kecepatan 5000 rpm selama 30 menit pada suhu $4^{\circ} \mathrm{C}$. Endapan yang diperoleh dilarutkan dalam $5 \mathrm{~mL}$ buffer fosfat $0,1 \mathrm{M}$ $\mathrm{pH}$ 7,5. Sebanyak $1 \mathrm{~mL}$ larutan diambil dan dilakukan proses desalting menggunakan kromatografi kolom filtrasi gel dengan matriks Sephadex G-25. Sebanyak 20 fraksi (masing-masing fraksi $5 \mathrm{~mL}$ ) hasil kolom dikumpulkan dan diukur konduktivitas dan serapannya pada panjang gelombang $280 \mathrm{~nm}$. Fraksifraksi dengan serapan pada panjang gelombang 280 yang tinggi dikumpulkan dan digunakan untuk penentuan kadar protein dan uji aktivitas enzim.

\section{Penentuan kadar protein dengan metode Lowry}

Sebanyak $200 \mu \mathrm{L}$ sampel ditambahkan dengan 2,5 $\mathrm{mL}$ pereaksi $\mathrm{C}\left(50: 1,2 \% \mathrm{Na}_{2} \mathrm{CO}_{3}\right.$ dalam $0,1 \mathrm{~N}$ $\mathrm{NaOH}: 0,5 \% \mathrm{CuSO}_{4} .5 \mathrm{H}_{2} \mathrm{O}$ dalam $1 \% \mathrm{Na}-\mathrm{K}$ Tartarat), dikocok dan didiamkan selama 10 menit pada suhu kamar. Kemudian ditambah dengan pereaksi D (Pereaksi Folin-Ciocalteau) sebanyak 0,25 mL, dikocok dan didiamkan selama 30 menit. Kemudian diukur serapannya pada panjang gelombang $750 \mathrm{~nm}$. Konsentrasi standar yang digunakan 0 - 2,5 mg/mL larutan BSA.

\section{Uji aktivitas asetil kolin esterase}

Diuji berdasarkan Ellman et al. (1961) dan

Taskin et al. (2007). Sebanyak $200 \mu \mathrm{L}$ larutan sampel yang akan diuji ditambahkan dengan $2 \mathrm{~mL}$ buffer fosfat $0,1 \mathrm{M} \mathrm{pH} 7.5$ dan ditambahkan dengan $150 \mu \mathrm{L}$ larutan DTNB 1,1 mM dan didiamkan. Setelah 10 menit, sebanyak $100 \mu \mathrm{L}$ asetilkolin iodida $10,5 \mathrm{mM}$ ditambahkan dan campuran ini diinkubasi selama 30 menit pada suhu $37^{\circ} \mathrm{C}$. Setelah 30 menit, serapan pada panjang gelombang $412 \mathrm{~nm}$ di ukur. Sebagai kontrol digunakan sampel yang sama, namun sebelum diuji sampel dipanaskan pada air mendidih dan disentrifugasi. Aktivitas enzim dihitung dengan menggunakan rumus:

Dengan:

$$
\mathrm{AU}=\frac{\mathrm{As}-\mathrm{Ak}}{0,001} \times \frac{1}{\mathrm{ti}} \times \frac{1}{\mathrm{Ve}}
$$

$\mathrm{AU}=$ aktivitas unit

As = serapan sampel yang diuji

$\mathrm{Ak}=$ serapan kontrol

$\mathrm{ti}=$ waktu inkubasi (30 menit)

$\mathrm{Ve}=$ volume enzim yang diuji $(0.2 \mathrm{~mL})$
Aktivitas unit enzim yang ditentukan berdasarkan kenaikan jumlah produk yang diukur pada panjang gelombang $412 \mathrm{~nm}$. Oleh karena itu, aktivitas unit enzim didefinisikan dengan kenaikan serapan sebesar 0,001 unit absorbansi diatas kontrol per $\mathrm{mL}$ enzim yang diuji per menit.

\section{Uji aktivitas esterase}

Diuji berdasaran Yu et al. (2003). Sebanyak $50 \mu \mathrm{L}$ larutan sampel yang akan diuji ditambah dengan $0,5 \mathrm{~mL}$ larutan buffer fosfat $0,1 \mathrm{M} \mathrm{pH} \mathrm{7,0}$ dan ditambahkan dengan $15 \mu \mathrm{L} \alpha$-naftil asetat 20 $\mathrm{mM}$ (dilarutkan dalam metanol) dan $2 \mathrm{~mL}$ larutan fast blue $(0.25 \mathrm{mg} / \mathrm{mL})$. Campuran ini diinkubasi selama 30 menit pada suhu $37^{\circ} \mathrm{C}$. Setelah selesai, kemudian serapan pada panjang gelombang $490 \mathrm{~nm}$ diukur dan digunakan untuk menghitung aktivitas unit enzim. Sebagai kontrol digunakan sampel yang sama, namun sebelum diuji sampel dipanaskan pada air mendidih dan disentrifugasi. Aktivitas enzim dihitung dengan menggunakan rumus:

Dengan:

$$
\mathrm{AU}=\frac{\mathrm{As}-\mathrm{Ak}}{0,001} \times \frac{1}{\mathrm{ti}} \times \frac{1}{\mathrm{Ve}}
$$

$\mathrm{AU}=$ aktivitas unit

As $=$ serapan sampel yang diuji

$\mathrm{Ak}=$ serapan kontrol

$\mathrm{ti}=$ waktu inkubasi (30 menit)

$\mathrm{Ve}=$ volume enzim yang diuji $(0,05 \mathrm{~mL})$

Aktivitas unit enzim yang ditentukan berdasarkan kenaikan jumlah produk yang diukur pada panjang gelombang $490 \mathrm{~nm}$. Oleh karena itu, aktivitas unit enzim didefinisikan dengan kenaikan serapan sebesar 0,001 unit absorbansi diatas kontrol per $\mathrm{mL}$ enzim yang diuji per menit.

\section{Uji aktivitas glutation S-transferase}

Diuji berdasrkan Habig et al. (1974). Sebanyak $200 \mu \mathrm{L}$ larutan sampel yang akan diuji ditambahkan dengan $0.86 \mathrm{~mL}$ larutan buffer fosfat 0,1 $\mathrm{M}$ pH 6,5. Kemudian ditambahkan sebanyak $100 \mu \mathrm{L}$ larutan glutation $10 \mathrm{mM}$ dan $20 \mu \mathrm{L}$ larutan CDNB 1 mM. Campuran ini kemudian diinkubasi selama 30 menit pada suhu $37^{\circ} \mathrm{C}$. Setelah inkubasi selesai, serapan pada panjang gelombang $340 \mathrm{~nm}$ diukur dan digunakan untuk mementukan aktivitas unit enzim. Sebagai kontrol digunakan sampel yang sama, namun sebelum diuji sampel dipanaskan pada air mendidih dan disentrifugasi. Aktivitas enzim dihitung dengan menggunakan rumus:

Dengan:

$$
\mathrm{AU}=\frac{\mathrm{As}-\mathrm{Ak}}{0,001} \times \frac{1}{\mathrm{ti}} \times \frac{1}{\mathrm{Ve}}
$$

AU $=$ aktivitas unit

As $=$ serapan sampel yang diuji

$\mathrm{Ak}=$ serapan kontrol

$\mathrm{ti}=$ waktu inkubasi (30 menit)

$\mathrm{Ve}=$ volume enzim yang diuji $(0,2 \mathrm{~mL})$ 
Aktivitas unit enzim yang ditentukan berdasarkan kenaikan jumlah produk yang diukur pada panjang gelombang $490 \mathrm{~nm}$. Oleh karena itu, aktivitas unit enzim didefinisikan dengan kenaikan serapan sebesar 0,001 unit absorbansi diatas kontrol per $\mathrm{mL}$ enzim yang diuji per menit.

\section{HASIL DAN PEMBAHASAN}

\section{Penentuan Tingkat Kepekaan Acuan}

Pengujian tingkat kepekaan acuan C. pavonana standar terhadap insektisida sintetik profenofos pada nilai LC $_{99}$ (Tabel 1), menunjukkan hasil sebesar $0,03294 \%$ pada metode pengujian efek kontak, dan $0,01900 \%$ pada metode pengujian efek residu pada daun pakan. Nilai $\mathrm{LC}_{99}$ ini menunjukkan bahwa profenofos 1,73 kali lebih beracun jika masuk melalui saluran pencernaan serangga uji dibanding jika masuk ke tubuh melalui integumen serangga, sedangkan pada nilai $\mathrm{LC}_{50}$ 1,07 kali lebih beracun. Telah diketahui bahwa profenofos merupakan racun lambung dan racun kontak yang berspektrum luas terhadap serangga hama (Matsumura,1985; Worthing, 1991).

\section{Penentuan Tingkat Resistensi}

Hasil pengujian toksisitas insektisida profenofos menunjukkan bahwa ketiga populasi lapang memiliki tingkat resistensi atau nisbah resistensi (NR) rendah $(1<\mathrm{NR} \leq 5)$ (Tabel 2 dan 3$)$. Nilai NR dengan metode uji perlakuan pakan lebih besar daripada nilai NR dengan metode kontak. Hal ini mengindikasikan bahwa resistensi terutama terjadi melalui saluran pencernaan serangga. Selain itu, rendahnya nilai NR melalui perlakuan kontak diduga disebabkan penurunan laju penetrasi insektisida melalui integumen serangga. Hal ini dapat disebabkan oleh perubahan dalam integumen seperti penebalan kutikula.

Beberapa kemungkinan yang menyebabkan tinggi rendahnya nilai NR yaitu antara lain perilaku petani dalam menggunakan insektisida sintetik yang kurang bijaksana untuk mengendalikan hama kubis, khususnya dalam hal pergiliran insektisida dan frekuensi penyemprotan. Hal ini sejalan dengan yang dilaporkan oleh Suharti (2000) bahwa pergiliran dan frekuensi aplikasi insektisida dapat mempengaruhi perkembangan serangga resisten. Penurunan tekanan seleksi, dapat terjadi seiring dengan berkurangnya frekuensi penggunaan insektisida, sehingga populasi serangga yang resisten dapat ikut berkurang, sedangkan pergiliran aplikasi insektisida yang dilakukan dapat menyebabkan rendahnya nilai NR pada populasi serangga lapang.

Tabel 1. Toksisitas insektisida profenofos terhadap C. pavonana standar laboratorium (48 jam setelah aplikasi (JSA))

\begin{tabular}{|c|c|c|c|c|}
\hline \multirow{2}{*}{ Metode pengujian } & \multicolumn{2}{|c|}{ Parameter regresi } & \multirow{2}{*}{ Nilai $\mathrm{LC}_{50}(\%)$ SK $(95 \%)$} & \multirow{2}{*}{ Nilai LC $99(\%)$ SK (95\%) } \\
\hline & $\mathrm{a} \pm \mathrm{sd}$ & $\mathrm{b} \pm \mathrm{sd}$ & & \\
\hline Kontak & $4,737 \pm 0,597$ & $1,627 \pm 0,208$ & $0,00122(0,00096-0,00152)$ & $0,03294(0,01707-0,09681)$ \\
\hline Perlakuan pakan & $5,609 \pm 0,644$ & $1,907 \pm 0,224$ & $0,00114(0,00077-0,00158)$ & $0,01900(0,00884-0,09776)$ \\
\hline
\end{tabular}

Tabel 2. Nisbah Resistensi C. pavonana terhadap insektisida profenofos dengan menggunakan metode pengujian efek kontak (48 JSA)

\begin{tabular}{cccccc}
\hline Populasi & \multicolumn{2}{c}{ Parameter regresi } & & Nilai LC $50(\%)$ SK (95\%) & NR \\
\cline { 2 - 3 } & $\mathrm{a} \pm \mathrm{sd}$ & $\mathrm{b} \pm \mathrm{sd}$ & & & \\
\hline Laboratorium (standar) & $4,737 \pm 0,597$ & $1,627 \pm 0,208$ & & $0,00122(0,00096-0,00152)$ & - \\
Desa Cikole & $3,897 \pm 0,713$ & $1,738 \pm 0,354$ & & $0,00573(0,00382-0,00744)$ & 4,69 \\
Desa Cibogo & $4,685 \pm 0,639$ & $1,615 \pm 0,225$ & & $0,00125(0,00100-0,00154)$ & 1,02 \\
Desa Kayu Ambon & $4,592 \pm 0,608$ & $1,613 \pm 0,214$ & & $0,00142(0,00076-0,00249)$ & 1,16
\end{tabular}

Keterangan : $\mathrm{a}=$ intersep; $\mathrm{sd}=$ standar deviasi; $\mathrm{b}=$ kemiringan garis regresi; $\mathrm{LC}=$ Lethal Concentration; SK = selang kepercayaan 95\%, NR: Nisbah Resistensi

Tabel 3. Nisbah Resistensi $C$. pavonana terhadap insektisida profenofos dengan menggunakan metode pengujian efek residu pada daun pakan (48 JSA)

\begin{tabular}{|c|c|c|c|c|}
\hline \multirow[t]{2}{*}{ Populasi } & \multicolumn{2}{|c|}{ Parameter regresi } & \multirow[t]{2}{*}{ Nilai $\mathrm{LC}_{50}(\%)$ sk $(95 \%)$} & \multirow[t]{2}{*}{ NR } \\
\hline & $\mathrm{a} \pm \mathrm{sd}$ & $\mathrm{b} \pm \mathrm{sd}$ & & \\
\hline Laboratorium (standar) & $5,609 \pm 0,644$ & $1,907 \pm 0,224$ & $0,00114(0,00077-0,00158)$ & - \\
\hline Desa Cikole & $3,073 \pm 0,687$ & $1,360 \pm 0,344$ & $0,00551(0,00245-0,00806)$ & 4,83 \\
\hline Desa Cibogo & $4,685 \pm 0,639$ & $1,615 \pm 0,225$ & $0,00126(0,00054-0,00226)$ & 1,10 \\
\hline Desa Kayu Ambon & $7,866 \pm 1,655$ & $2,953 \pm 0,646$ & $0,00217(0,00156-0,00269)$ & 1,90 \\
\hline
\end{tabular}


Pertanaman kubis di Desa Cikole sebagian besar berada di Balitsa (Balai Penelitian Tanaman Sayur) dan sekitarnya. Pada lokasi ini, area pertanaman hortikultura khususnya tanaman dari famili Brassicaceae cukup luas dengan frekuensi penyemprotan insektisida 3 - 5 hari sekali berdasarkan wawancara yang dilakukan penulis dengan petani pemilik lahan. Frekuensi penyemprotan insektisida yang intensif pada desa Cikole dibanding dengan kedua desa lainnya menyebabkan NR yang tinggi. Dono et al. (2010) melaporkan bahwa interval penyemprotan insektisida yang terlalu sering dilakukan dapat mengakibatkan terjadinya seleksi yang lebih cepat terhadap serangga - serangga rentan, sehingga pada populasi berikutnya akan didominasi oleh serangga - serangga yang resisten terhadap insektisida. Selain pergiliran dan frekuensi aplikasi, peningkatan dosis aplikasi insektisida dapat meningkatkan tekanan seleksi terhadap serangga rentan dan peningkatan populasi serangga resisten. Semakin lama proses ini berjalan, maka semakin banyak serangga rentan yang terseleksi dan semakin banyak pula serangga resisten yang berkembang di area tersebut.

Pertanaman kubis di Desa Cibogo dilakukan secara polikultur, serta berada di sekitar jalan raya dan pemukiman penduduk. Interval penyemprotan yang dilakukan oleh petani di desa tersebut hanya $10-14$ hari sekali, lebih jarang daripada Desa Cikole dan Desa Kayu Ambon. Interval penyemprotan yang jarang dilakukan menyebabkan rendahnya tekanan seleksi yang terjadi, sehingga serangga rentan di wilayah tersebut dapat tetap tumbuh dan berkembang.

Keadaan area pertanaman kubis di Desa Kayu Ambon tidak jauh berbeda dengan Desa Cibogo, yaitu berada di sekitar pemukiman penduduk. Perbedaan yang terdapat pada kedua desa tersebut, berada pada cara budidaya. Di Desa Kayu Ambon, kubis ditanam secara monokultur. Pola tanam monokultur secara terus-menerus (berkesinambungan) memperbesar tekanan seleksi terhadap C. pavonana sehingga dapat mendorong munculnya serangga yang resisten. Tekanan seleksi yang terjadi di Desa Kayu Ambon lebih rendah daripada Desa Cikole, karena interval penyemprotan yang dilakukan oleh petani yaitu sekitar 6-8 hari sekali. Akan tetapi, tingkat resistensi rendah $(1<\mathrm{NR} \leq 5)$ terjadi di Desa Kayu Ambon selain karena pola pertanaman monokultur, petani di desa tersebut seringkali meningkatkan dosis aplikasi pestisida hingga $10 \mathrm{ml} /$ liter (dosis anjuran 1,5 $\mathrm{ml} /$ liter), terutama jika terjadi dugaan resistensi.

Untuk mengetahui mekanisme detoksifikasi yang berperan dalam resistensi C. pavonana terhadap profenofos dapat dilakukan uji sederhana dengan penambahan piperonilbutoksida (PBO) pada perlakuan dengan profenofos. Piperonilbutoksida merupakan senyawa sinergis penghambat enzim detoksifikasi yang umum yaitu Mixed Function Oxidase (MFO) (Ahmad et al. 2015).

\section{Kepekaan Serangga Resisten terhadap Ekstrak Biji A. indica}

Serangga populasi lapang yang berasal dari ketiga desa diuji kepekaannya terhadap ekstrak biji $A$. indica karena menunjukkan resistensi terhadap insektisida profenofos walaupun dalam tingkat resistensi rendah $(1<\mathrm{NR} \leq 5)$. Hasil pengujian toksisitas insektisida botani dari ekstrak $A$. indica terhadap ketiga populasi $C$. pavonana lapang yang diuji, menunjukkan adanya kepekaan terhadap insektisida botani tersebut. Hal ini ditunjukkan dengan nilai NR yang kurang dari satu pada ketiga populasi C. pavonana lapang yang diuji (Tabel 4).

Tabel 4. Nisbah resistensi (NR) C. pavonana terhadap insektisida botani ekstrak biji $A$. indica dengan menggunakan metode perlakuan pakan.

\begin{tabular}{ccccc}
\hline \multirow{2}{*}{ Populasi } & \multicolumn{2}{c}{ Parameter regresi } & & \\
& $\mathrm{a} \pm \mathrm{sd}$ & $\mathrm{b} \pm \mathrm{sd}$ & Nilai LC $50(\%) \mathrm{sk}(95 \%)$ & $\mathrm{NR}$ \\
\hline Laboratorium (standar) & $5,201 \pm 0,1267$ & $2,734 \pm 0,705$ & $0,84412(0,74565-1,07120)$ & - \\
Desa Cikole & $1,352 \pm 0,158$ & $7,252 \pm 0,831$ & $0,65094(0,61554-0,68452)$ & 0,77 \\
Desa Cibogo & $1,766 \pm 0,185$ & $8,069 \pm 0,919$ & $0,60406(0,56948-0,63454)$ & 0,71 \\
Desa Kayu Ambon & $1,111 \pm 0,147$ & $5,854 \pm 0,776$ & $0,64579(0,60212-0,69898)$ & 0,76 \\
\hline Keterangan : $\quad$ a = intersep; sd= standar deviasi; & b = kemiringan garis regresi; LC= Lethal Concentration; &
\end{tabular}

Data yang disajikan pada Tabel 4 menunjukkan bahwa $C$. pavonana yang resisten terhadap insektisida sintetik profenofos dapat dikendalikan dengan menggunakan insektisida botani ekstrak biji $A$. indica. Hal ini dikarenakan adanya perbedaan cara kerja dari masing-masing insektisida tersebut. Insektisida botani ekstrak biji $A$. indica memiliki cara kerja yang lebih beragam dalam mematikan $C$. pavonana, sedangkan insektisida sintetik profenofos memiliki cara kerja mengganggu transmisi impuls syaraf serangga. Insektisida golongan organofosfat bekerja pada celah pertautan syaraf. Organofosfat berikatan dengan asetilkolinesterase, enzim yang memecah asetilkolin, sehingga asetilkolinesterase tidak dapat mengurai neurotransmitter tersebut menjadi asam asetat dan kolin (Matsumura, 1985; Stenersen, 2004; Kazemi et al., 2012).

Indiati (2009) melaporkan bahwa senyawa aktif dalam ekstrak biji $A$. indica dapat membunuh 
hama dengan cara memberi pengaruh terhadap daya makan, pertumbuhan, daya reproduksi, proses ganti kulit, penghambat perkawinan dan komunikasi seksual, penurunan daya tetas telur, penghambat pembentukan kitin, serta sebagai pemandul. Asadirakhtin dan minyak mimba efektif terhadap Aphis glycines (Homoptera: Aphididae), (Kraiss \& Cullen, 2008). Ekstrak biji A. indica ,mengandung azadiraktin yang bersifat sebagai zat penghambat perkembangan (metamorfosis) serangga (Mordue et al., 1998; Kraiss \& Cullen, 2008). Zakiah et al. (2003) melaporkan bahwa ekstrak biji $A$. indica mengandung senyawa triterpenoid yang bersifat antifeedant (penolak makan pada serangga) dan mengganggu pertumbuhan serta reproduksi serangga. Terganggunya perkembangangan serangga diakibatkan gangguan pada hormon 20hidroksiekdison sehingga menghambat perkembangan yang normal. Selain itu perlakuan azadirakhtin juga mengakibatkan gangguan hormon protorasikotropik (PTTH) (Barnby \& Klocke,1990; Chapman, 1998; Klowden, 2002).

Cara kerja ekstrak biji $A$. indica yang berbeda dengan cara kerja insektisida golongan profenofos sehingga dari hasil pengujian ini juga menunjukkan tidak terjadinya resistensi ganda pada $C$. pavonana sehingga strategi pengendaliannya dapat dilakukan dengan menggunakan insektisida yang berbeda golongan bahan aktifnya atau berbeda mekanisme kerja dan mekanisme detosifikasinya. Serangga yang mengalami resistensi ganda yaitu jika serangga tersebut menjadi resisten terhadap dua atau lebih kelompok insektisida yang sebelumnya belum pernah digunakan untuk mengendalikan serangga tersebut atau suatu insektisida yang mempunyai cara kerja atau jalur metabolisme yang berbeda (FAO, 2012; Georghiou \& Saito, 1983).

\section{Aktivitas Enzim yang berperan dalam mekanisme resistensi $C$. pavonana terhadap insektisida profenofos}

Data aktivitas spesifik enzim asetil kolin esterase menunjukkan bahwa sampel yang berasal dari Cibogo memiliki aktivitas asetilkolin esterase tertinggi dibandingkan dengan standar laboratorium. Sampel-sampel dari daerah lain tidak menunjukkan perbedaan yang nyata dengan standar. Sampel dari Cikole menunjukkan aktivitas asetilkolin esterase yang lebih kecil dibandingkan standard (Gambar 1.).

Asetilkolinesterase (EC 3.1.1.7) termasuk enzim hidrolase, esterase serin yang memecah neurotransmitter, asetilkolin. Enzim ini merupakan target terbesar dari insektisida, senyawa organofosfat dan karbamat, dimana senyawa insektisidal akan mempengaruhi sisi aktif enzim sehingga hidolisis asetikolin terhalang dan meyebabkan serangga mati (Walsh, 2001). Asetilkolin merupakan enzim yang memegang peranan penting dalam sistem syaraf baik pada vertebrata maupun invertebrata
Asetilkolinesterase menghidrolisis asetilkolin dengan membentuk intermediet asetil-asetikolinesterase yang kemudian melepas asetat Gambar 1). Kolin yang terlepas didaur ulang pada sel syaraf pre-sinapsis (Massoulie., et. al., 1999. dalam Gouri 2004). Dengan kata lain, asetilkolinesterase merubah Asetilkolin (senyawa yang dapat meracuni syaraf) menjadi kolin dan asetat (senyawa yang tidak berbahaya bagi tubuh).

Aktivitas glutation S-transferase paling tinggi ditunjukkan oleh sampel $C$. pavonana yanag berasal dari Desa Cibogo diikuti oleh Kayu Ambon dan Cikole keempat sampel ini memiliki aktivitas spesifik yang lebih besar dibandingkan dengan standar laboratorium. Namun, untuk sampel dari Cikole, tidak berbeda nyata dengan sampel standard karena memiliki simpangan baku yang cukup besar. Sampel dari pangalengan menunjukkan aktivitas yang lebih rendah dibandingkan dengan standar (Gambar 2).

Glutation S-transferase (EC 2.5.1.18) adalah sekelompok enzim yang mengkatalisis senyawasenyawa glutation, yang memiliki gugus - SH dengan menetralkan gugus elktrofilik menjadi glutation terkonjugasi yang larut dalam air (Habig et.al., 1974). Reaksinya juga dipercaya sebagai jalur penting yang dapat mendetoksifikasi senyawa senobiotik, melalui perubahan produk katalitik menjadi metabolit yang lebih mudah di ekskresikan. Pada tubuh serangga, glutaton transferase mengkatalisis reaksi metabolism insektisida organofosfor dan organoklorin. Enzim ini juga terlibat dalam perkembangan resistensi terhadap senyawa-senyawa organofosfor dan organoklorin. Selain itu, glutation transferase dipercaya memegang peranan penting dalam tubuh serangga herbivora melalui detoksifikasi tumbuhan beracun (Wadleigh and $\mathrm{Yu}, 1988$ ).

Sampel populasi $C$. pavonana yang berasal dari desa Kayu Ambon, cibogo dan Cikole menunjukkan aktivitas esterase yang lebih tinggi dibandingkan populasi $C$. pavonana standar. Aktivitas esterase paling tinggi ditunjukkan oleh sampel dari Kayu Ambon. Sampel lain tidak menunjukkan perbedaan yang nyata (Gambar 3)

Untuk pengujian aktivitas enzim, sampel terlebih dahulu dimurnikan dengan pengendapan protein menggunakan garam ammonium sulfat dan proses penghilangan garam (desalting) menggunakan kromatografi kolom filtrasi gel dengan matriks Sephadex G-25. Hal ini dilakukan karena homogenat berwarna hijau pekat yang kemungkinan besar disebabkan karena adanya klorofil pada saluran pencernaan larva dari asupan daun yang ikut terekstraksi ketika dilakukan proses homogenisasi. Adanya klorofil ini dikhawatirkan dapat mengganggu pengukuran menggunakan alat spektrofotometer. Oleh karena itu dilakukan tahap pemisahan protein, termasuk di dalamnya enzim yang diinginkan, dari komponen klorofil.

Resistensi terhadap insektisida dapat terjadi karena salah satu mekanisme seperti yang dituliskan 
Fournier et al. (1992) serta Pasteur \& Raymond, (1996) yaitu berkurangnya penetrasi insektisida ke dalam serangga, insektisida dapat dimetabolisme lebih efisien dengan bantuan enzim-enzim oksidase (contoh: sitokrom P450 oksidase), glutation S- transferase dan hidrolase (contoh: esterase), dan target insektisida mengalami perubahan (terjadinya mutasi pada target senyawa insektisidal).

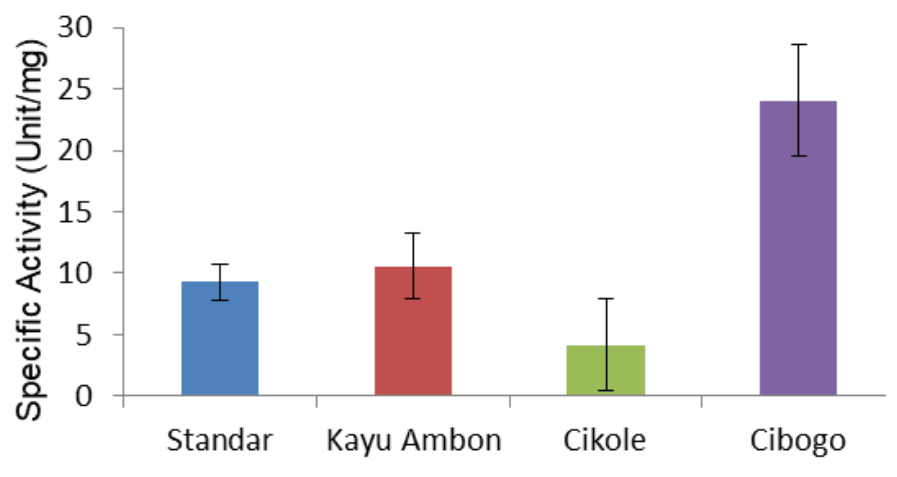

Daerah asal C. pavonana

Gambar 1. Aktivitas asetil kolin esterase sampel larva C. pavonana populasi lapang dan populasi standard

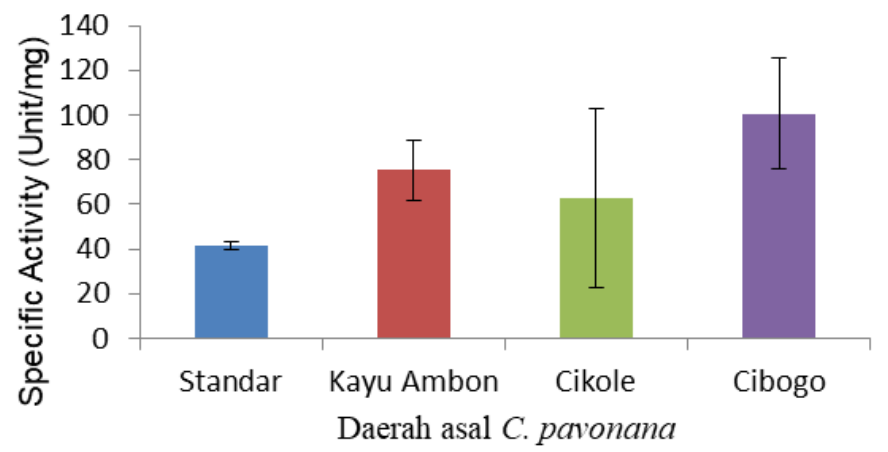

Gambar 2. Aktivitas glutation S-transferase sampel larva C. pavonana populasi lapang dan populasi standard

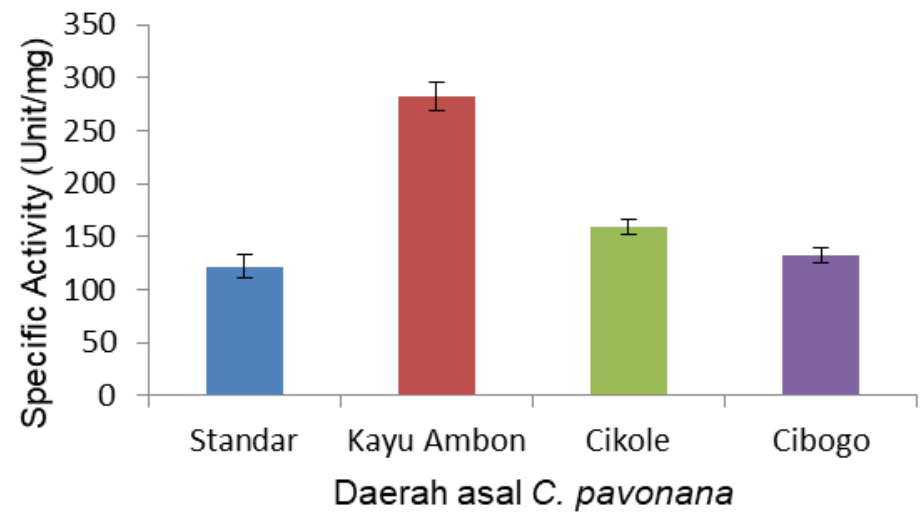

Gambar 3. Aktivitas esterase sampel larva C. pavonana populasi lapang dan populasi standard

Resistensi yang berkaitan dengan enzim dapat terjadi dengan terjadinya mutasi pada enzim yang dimaksud sehingga meningkatkan aktivitas katalitik enzim yang bersangkutan (Hemingway et al., 2002, Hemingway et al., 2004, Walsh et al., 2001) dan/atau meningkatnya jumlah enzim yang diekspresikan (Field et al., 1999, Fournier et al., 1992). Dengan meningkatnya aktivitas total enzim yang bersangkutan, maka konversi senyawa-senyawa toksik insektisidal menjadi senyawa yang tidak bersifat toksik dapat berlangsung lebih efektif.

Hasil analisis tiga enzim (asetilkolin esterase, esterase dan glutation S-transferase) pada penelitian ini menunjukkan bahwa aktivitas enzim tertinggi berbeda-beda antara satu sampel dengan sampel yang lain. Hal ini menunjukkan bahwa masing-masing sampel dapat mengembangkan sistem detoksifikasi yang berbeda. Sebagai contoh, sampel dari Cibogo 
menunjukkan aktivitas asetilkolin esterase dan glutation S-transferase yang tinggi dibandingkan standar namun aktivitas esterase pada sampel ini rendah dibandingkan standar. Sedangkan sampel dari Kayu Ambon menunjukkan aktivitas glutation Stransferase dan esterase yang tinggi, namun aktivitas asetil kolin esterase pada sampel ini lebih rendah dibandingkan standar. Hal ini dapat terjadi karena sampel-sampel yang diuji terpapar terhadap senyawa insektisidal yang berbeda sehingga sistem detoksifikasi yang dikembangkan juga berbeda-beda.

Tingginya aktivitas yang ditunjukkan, dapat terjadi karena adanya mutasi pada enzim yang bersangkutan sehingga mengakibatkan meningkatnya aktivitas atau mungkin juga dapat terjadi karena bertambahnya ekspresi enzim tersebut sehingga aktivitas enzim yang bersangkutan menjadi lebih tinggi dibandingkan standar. Tingginya aktivitas enzim-enzim tersebut akan mengakibatnya meningkatnya resistensi terhadap senyawa-senyawa insektisidal, karena meningkatnya kemampuan serangga tersebut untuk mengkonversi senyawa insektisidal yang toksik menjadi senyawa lain yang bersifat kurang toksik.

Untuk mengkonfirmasi apakah tingginya aktivitas enzim-enzim yang diuji terjadi karena adanya mutasi pada enzim atau meningkatnya ekspresi enzim tersebut, perlu dilakukan penelitian lebih lanjut pada tingkat molekular dengan mempelajari struktur dan tingkat ekspresi enzimenzim tersebut dibandingkan terhadap standar laboratorium.

Secara umum, ketiga enzim memiliki aktivitas terbesar pada kontrol. Sedangkan aktivitas sampel yang terpapar pestisida tidak seragam. Sampel dengan aktivitas tertinggi asetilkolinesterase adalah sampel dari desa simpang; aktivitas esterase tertinggi dari padasuka; dan aktivitas Glutation S-transferase tertinggi berasal dari Cikandang.

Dari hasil penelitian tersebut dapat disimpulkan bahwa sampel yang terpapar insektisida memilliki aktivitas enzim lebih rendah dibanding kontrol sebab pada kontrol, kemungkinan sisi aktif enzim masih berfungsi dengan baik, sedangkan pada yang terpapar insektisida, sebagian besar sisi aktif molekul-molekul enzim telah terblok, Kemudian ketidakseragaman aktivitas sampel yang terpapar insektisida kemungkinan disebabkan sampel-sampel yang terpapar senyawa insektisida berbeda sehingga sistem detoksifikasi yang dikembangkan juga berbeda-beda.

Beberapa enzim dalam tubuh serangga mampu mengkatalisis senyawa-senyawa berbahaya menjadi senyawa yang tidak berbahaya bagi tubuhnya. Sehingga aktivitas enzim ini sangat berkaitan erat dengan resistensi serangga terhadap zat-zat racun, seperti insektisida.

\section{KESIMPULAN DAN SARAN}

Populasi Crocidolomia pavonana yang berasal dari desa Cikole, Desa Cibogo dan Desa Kayu Ambon terindikasi memiliki tingkat resistensi rendah (Nisbah Resistensi (NR) berkisar $1<\mathrm{NR} \leq 5$ ) berturut turut yaitu 4,69 dan 4,83; 1,02 dan 1,1 serta 1,16 dan 1,9 baik untuk pengujian efek kontak maupun perlakuan pakan. Berdasarkan nilai NR kedua metode pengujian tersebut, mekanisme resistensi terindikasi terutama terjadi pada sistem pencernaan serangga. Hasil analisis tiga enzim (asetilkolin esterase, esterase dan glutation S-transferase) pada penelitian ini menunjukkan bahwa aktivitas enzim tertinggi berbeda-beda antara sampel dari suatu daerah dengan sampel asal daerah lain. Hal ini menunjukkan bahwa masing-masing sampel dapat mengembangkan sistem detoksifikasi yang berbeda.

Populasi C. pavonana asal Desa Cikole, Desa Cibogo dan Kayu Ambon peka terhadap ekstrak biji A.indica sehingga ekstrak biji $A$. indica berpotensi sebagai alternatif pengendalian $C$. pavonana yang resisten terhadap insektisida sintetik profenofos.

\section{UCAPAN TERIMA KASIH}

Penelitian ini merupakan bagian dari penelitian fundamental yang dibiayai oleh dana DIPA Universitas Padjadjaran sesuai dengan surat keputusan rektor Universitas Padjadjaran No. 3871b/H6.28/TU/2010. Kepada penyandang dana disampaikan terima kasih.

\section{DAFTAR PUSTAKA}

Ahmad I, Susanti S, Kustiati, Yusmalinar S, Rahayu R, \& Hariani N. 2015. Resistensi lalat rumah, Musca domestica Linnaeus (Diptera: Muscidae) dari empat kota di Indonesia terhadap permetrin dan propoksur. Jurnal Entomologi Indonesia. 12 (3): 123-128.

Aktar MdW, Sengupta D, \& Chowdhury A. 2009. Impact of pesticides use in agriculture: their benefits and hazards.Interdisc Toxicol. 2009. 2(1): 1-12.

Barnby MA \& Klocke JA. 1990. Effects of azadirachtin on levels of ecdysteroids and prothoracicotropic hormone-like activity in Heliothis virescens (Fabr.) larvae. J. Insect Physiol.: 36 (2): 125-131.

Chapman RF. 1998. The Insects: Structure and Function. Forth Edition. Camberidge: Cambridge University Press. PP. 570-582.

Dono D, Ismayana S, Idar, Prijono D, \& Muslikha I. 2010. Status dan mekanisme resistensi biokimia Crocidolomia pavonana (F) (Lepidoptera: Crambidae) terhadap Insektisida organofosfat serta kepekaannya terhadap insektisida botani ekstrak biji Barringtonia asiatica. Jurnal Entomologi Indonesia. 7 (1): 9 $-27$.

Dono D, Natawigena WD, \& Kharismansyah HR. 2014. Resistance status of Crocidolomia 
pavonana F. (Lepidoptera: Crambidae) from Pasirwangi Garut, West Java to the insecticide profenofos and its susceptibility to the methanolic leaf extract of Nicotiana tabacum L. (Solanaceae). Journal of ISSAAS. 20 (2): 121-130.

Ellman GL, Courtney KD, Andres V, Featherstone RM. 1961. A new and rapid colorimetric determination of acetylcholinesterase activity. Biochem Pharmacol. 7(2):88-95. doi:10.1016/0006-2952(61)90145-9

Field L, Blackman RL, Tyler-Smith,C \& Devonshire, AL. 1999. Relationship between amount of esterase and gene copy number in insecticideresistant Myzus persicae (Sulzer). Biochemistry Journal, 339, 737-742.

Fournier D, Bride Jj.-M, Hoffmann F \& Kar F. 1992. Acetylcholinesterase: two types of modifications confer resistance to insecticide. Journal of Biological Chemistry, 267, 1427014274.

Gouri A. 2004. Acetylcholinesterase Activity and Isozyme Pattern in Normal and Lithiumtreated Developing Chick Brain. Master of Science Thesis. Department of Life Sciences. Sophia College

Georghiou GP \& Saito T. 1983. Pest Resistance to Pesticides. New York: Plenum Press.

[FAO] Food and Agricultural Organization. 2012. Guidelines on Prevention and Management of Pesticide Resistance. Food and Agricultural Organization.

Habig W., Pabst M., Jakoby W. Glutation STransferase The first enzymatic step in mercapturic acid formation. 1974. J Biol Chem. 249(22): 7130-7139. http://strings. sandwich.net/texts/mine/prose/TheFirst.rtf.

Hemingway,J., Field, L. \& Vontas, J. 2002. An overview of insecticide resistance. Science, 298, 96-97.

Hemingway, J., Hawkes, N. J., Mccarroll, L. \& Ranson, H. (2004) The molecular basis of insecticide resistance in mosquitoes. Insect Biochemistry and Molecular Biology, 34: 653665.

Indiati SW. 2009. Mimba Pestisida Nabati Ramah Lingkungan. Balai Penelitian Tanaman Kacang-kacangan dan Umbi-umbian. Malang. Available online at : www.balitkabi. litbang.deptan.go.id (accessed on August 1, 2011).

Isman MB, Arnason JT, \& Towers GHN. 1995. Chemistry and biological activity of ingredients of other species of Meliaceae. In Schumutterrer $\mathrm{H}$ (Ed.) The Neem Tree Azadirachta indica A. Juss, and Other Meliaceous Plants: Sources of Unique Natural Products for Integrated Pest Management, Madicine, Industry and Other Purpose. Weinheim (Germany): VCH. P 652-666.
Mordue AJ, Simmonds MSJ, Ley SV, Blaney W M, Mordue W, Nasiruddin M \& Nisbet AJ. 1998. Actions of azadirachtin, a plant allelochemical, against insects. Pestic. Sci., 54: 277-284.

Kazemi M, Tahmasbi AM, Valizadeh R, Naserian AA \& Soni A. 2012. Organophosphate pesticides: A general review . Agricultural Science Research Journals. 2 (9): 512- 522.

Klowden MJ. 2002. Physiological system in insect. Callifornia, USA: Academic Press. PP. 1-34.

Kraiss H \& Cullen E M. 2008. Insect growth regulator effects of azadirachtin and neem oil on survivorship, development and fecundity of Aphis glycines (Hemiptera: Aphididae) and its predator, Harmonia axyridis (Coleoptera: Coccinellidae).Pest Manag. Sci., DOI: 10.1002/ps.1541. 1526-498X

LeOra Software. 1987. POLO-PC User's Guide. Petaluma (US): LeOraSoftware

Matsumura F. 1985. Toxicology of Insecticides. Ed ke-2. New York: PlenumPress.

Pasteur N. \& Raymond, M. 1996. Insecticide resistance genes in mosquitoes: their mutations, migration, and selection in field populations. Journal of Heredity, 87: 444-449.

Prijono D \& Hassan E. 1992. Life cycle and demography of Crocidolomia binotalis Zeller (Lepidoptera: Pyralidae) on broccoli in the laboratory. Indon J Trop Agric 4: 18-24.

Rodríguez MM, Bisset JA, \& Fernández D. 2007. Levels of insecticide resistance and resistance mechanisms in aedes aegypti from some Latin American countries. Journal of the American Mosquito Control Association, 23 (4): 420429.

Santoso KN. 1997. Deteksi resistensi profenofos terhadap Crocidolomia binotalis Zell. (Lepidoptera : Pyralidae) dan pengaruh konsentrasi subletal profenofos terhadap berat pupa, keberhasilan pupa menjadi imago, reproduksi dan lama hidup imago. (skripsi). Jurusan Hama dan Penyakit Tumbuhan, Fakultas Pertanian, Institut Pertanian Bogor.

Sastrosiswojo S. 1987. Integration of biological and chemical control of the diamondback moth (Plutella xylostella L. ; Lepidoptera: Yponomeutidae) on cabbage. $\mathrm{PhD}$ Thesis. University of Padjadjaran, Bandung. 388 p.

Schmutterer H. (ed.). 1995. The Neem Tree Azadirachta indica A. Juss. and Other Meliaceous Plants: Sources of Unique Natural Products for Integrated Pest Management, Medicine, Industry and Other Purposes. VCH, Weinheim, Germany.

Schmutterer H, \& Sing RP. 1995. List of insect pest susceptible to neem products.. Di dalam: Schmutterer H, editor. The Neem Tree Azadirachta indica A. Juss. and Other Meliaceous Plants: Sources of Unique Natural Products for Integrated Pest Management, 
Medicine, Industry and Other Purposes. Germany: VCH. pp 326-365.

Sharma HC, Leuschner K, Sankaram AVB, Marthanda-Murthi M, Bhaskariah $\mathrm{K}$, Subramanyam M, \&Sultana M. 1984. Insect antifeedant and growth inhibitors from Azadirachta indica. In Schmutterer $\mathrm{H}$, Ascher KRS. (Eds.). Natural Pesticides from The Neem Tree and Other Tropical Plants.pp. 291320.

Soemawinata RAT, Prijono D. \& Santoso TH. 1993. Status resistensi wereng coklat Nilaparvata lugens Stal (Homoptera : Delphacidae) terhadap beberapa jenis insektisida. Bul HPT 7(1): 11-22.

Soeriaatmadja, R.E. \& Duskarno. 1990. The efficacy of teflubenzuron, flufenoxuron andchlorfluazuron against Plutella xylostella L. and Crocidolomia binotalis (Zell.) on cabbage. Bull. Penel. Hort. 19: 117-132.

Stenersen J. 2004. Chemical Pesticides Mode Of Action And Toxicology. CRC Press. Boca Raton, Florida, USA.

Suharti T. 2000. Status Resistensi Crocidolomia binotalis Zell. (Lepidoptera: Pyralidae) terhadap Insektisida Profenofos (Curacron 500EC) dari Tiga Daerah di Jawa Barat (Garut, Pengalengan, Lembang). Skripsi. Bogor : Institut Pertanian Bogor.

Taşkin V, Küçükakyüz K, Arslan T, Çöl B, Taşkin BG. The biochemical basis of insecticide resistance and determination of esterase enzyme patterns by using PAGE in field collected populations of Drosophila melanogaster form Muğla Province of Turkey. J Cell Mol Biol. 2007;6(1):31-40.

Untung K. 2006. Manajemen Resistensi Pestisida Sebagai Penerapan Pengelolaan Hama Terpadu. Available online at : www.kasumbogo.staff.ugm.ac.id(accessed on Maret 27, 2008).

Wadleigh, RW \& Yu SJ. 1988. Detoxification of Isothiocyanate Allalochemicals by Glutathione Transferase in Three Lepidopterous Species. Journal of Chemical Ecology, 14.

Walsh, SB, Dolden TA, Moores GD, Kristensen M, Lewis T, Devonshire AL \& Williamson, MS. 2001. Identification and characterization of mutations in housefly (Musca domestica) acetylcholinesterase involved in insecticide resistance. Biochemistry Journal, 359, 175181.

Worthing, R.C. 1991. The Pesticide Manual: A World Compendium. Ed. ke-9. Farnham: The British Crop Protection Council.

Yu SJ, Nguyen SN, Abo-Elghar GE. 2003. Biochemical characteristics of insecticide resistance in the fall armyworm, Spodoptera frugiperda (J.E. Smith). Pestic Biochem Physiol.;77(1): 1-11. doi:10.1016/S00483575(03)00079-8

Zakiah Z, Marwani E \& Siregar AH. 2003. Peningkatan Produksi Azadirachtin dalam Kultur Suspensi Sel Azadirachta indica A.Juss melalui Penambahan Skualen. Jurnal Matematika dan Sains. 8(4): 141-146.

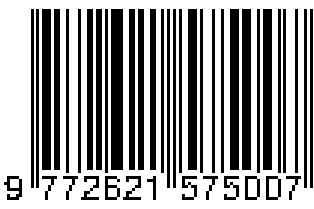

